\title{
Managing Paper and Pulp Industry By-Product Waste Utilizing Sludge as a Bio-Fertilizer
}

\author{
Sania Fahim", Numrah Nisar', Zaira Ahmad ${ }^{1}$, Zahra Asghar ${ }^{1}$, Amir Said², \\ Saima Atif ${ }^{1}$, Nadia Ghani', Naseem Qureshi ${ }^{3}$, Gul Afshan Soomro ${ }^{4}$, \\ Munawar Iqbal ${ }^{5}$, Arif Nazir ${ }^{*}$
}

\author{
${ }^{1}$ Department of Environmental Sciences, LCWU, Lahore-Pakistan \\ ${ }^{2}$ Research \& Development Packages Ltd. Lahore, Lahore-Pakistan \\ ${ }^{3}$ Department of Chemistry, Karakoram International University, Gilgit-Baltistan, Pakistan \\ ${ }^{4}$ Institute of Chemistry, Shah Abdul Latif University, Khairpur, Sindh, Pakistan \\ ${ }^{5}$ Department of Chemistry, The University of Lahore, Lahore-Pakistan
}

Received: 26 September 2017

Accepted: 1 January 2018

\begin{abstract}
An enormous amount of waste material (sludge) generated from paper and pulp industries is either dumped or incinerated. However, this pulp is an enriched source of macronutrients and can be employed on agricultural land to improve its fertility. The current study was therefore performed to analyze phosphorus $(\mathrm{P})$ and calcium $(\mathrm{Ca})$ by flame photometer, nitrogen $(\mathrm{N})$ by Kjeldahl method, and magnesium $(\mathrm{Mg})$ by back titration from sludge. The application of sludge significantly increases macronutrients in the plants lady finger (Abelmoschus esculentus) and garden mint (Mentha sachalinensis).We applied primary (initial husk treatment) and secondary (after primary treatment) sludge to observe the growth of Abelmoschus esculentus and Mentha sachalinensis. However, primary sludge showed the highest concentration of nutrients, i.e., $96.5 \% \mathrm{P}, 99.6 \% \mathrm{~N}, 86 \% \mathrm{Ca}$, and $0.008 \% \mathrm{Mg}$. The application of paper and pulp waste to the soil indicates that these bio-solids are good for soil fertility, biomass production, and plant growth; however, they are slightly less efficient than synthetic fertilizers. However, the synthetic fertilizers are probable candidates for holding heavy metals, so these bio-solids can be considered a better source for soil fertility.
\end{abstract}

Keywords: sludge, bio-solids, macronutrients, Abelmoschus esculentus, Mentha sachalinensis

\section{Introduction}

Solid waste generation is increasing due to increased population, industrialization, urbanization, economic

*e-mail: anmalik77@gmail.com growth, and improved standard of living [1]. The demand for paper and pulp is growing persistently across the globe due to its abundant consumption. The development of society can be indexed by the paper it consumes [2]. The pulp and paper industry has a fundamental role in the worldwide economy. Global manufacturing of the paper and pulp industry is predicted to increase by 
Table 1. Chemical composition and application of different sludge sources.

\begin{tabular}{|c|c|c|c|c|c|}
\hline Sr. \# & Sludge Types & Composition & Application & Remarks & Reference \\
\hline 1 & $\begin{array}{l}\text { Sewage sludge } \\
\text { (wet \& pelleted) }\end{array}$ & $\begin{array}{c}\text { Dry matter, organic } \mathrm{C}, \mathrm{N}, \mathrm{P}, \\
\mathrm{Ca}, \mathrm{Mg}, \mathrm{Na}, \mathrm{Pb}, \mathrm{Cd}, \mathrm{Ni}, \mathrm{Hg} \\
\mathrm{Zn}, \mathrm{Cu}, \mathrm{Cr}\end{array}$ & $\begin{array}{l}\text { Utilization of biogenic com- } \\
\text { ponents from sewage sludge } \\
\text { by the Virginia fanpetals }\end{array}$ & $\begin{array}{l}\text { Wet sludge gave positive } \\
\text { results while biomass of } \\
\text { pelleted sludge was lower }\end{array}$ & {$[4]$} \\
\hline 2 & $\begin{array}{l}\text { Combined paper } \\
\text { mill biosolids }\end{array}$ & $\begin{array}{l}\text { Total P, Total N, Total C, Total } \\
\mathrm{K} \text {, heavy metals, pathogenic } \\
\text { population }\end{array}$ & $\begin{array}{l}\text { Repeated application of PB } \\
\text { cause leaching and metallic } \\
\text { pollution }\end{array}$ & $\begin{array}{l}\text { No E. coli pollution, } \\
\text { positive impact of } \mathrm{PB}\end{array}$ & [5] \\
\hline 3 & $\begin{array}{l}\text { Manure and paper } \\
\text { mill sudge }\end{array}$ & $\begin{array}{l}\mathrm{C} / \mathrm{N} \text { ratio }<15 \text { and paper mill } \\
\text { sludge with } \mathrm{C} / \mathrm{N}>15\end{array}$ & $\begin{array}{c}\text { App. effects on potato yield, } \\
\text { N efficiency and disease } \\
\text { incidence. }\end{array}$ & $\begin{array}{l}\text { Composted Manure gave } \\
\text { low result then PMS, use } \\
\text { of } \mathrm{N} \text { fertilizers }\end{array}$ & [6] \\
\hline 4 & $\begin{array}{l}\text { Primary and } \\
\text { secondary pms }\end{array}$ & $\begin{array}{l}\text { Toxic }+ \text { heavy metals conc. } \\
\text { and macronutrients conc. }\end{array}$ & $\begin{array}{l}\text { Transformation of elemental } \\
\text { toxic metals into immobile } \\
\text { fractions through rotary } \\
\text { drum composting }\end{array}$ & $\begin{array}{l}\text { Positive response of the } \\
\text { use of compost as it con- } \\
\text { trols leaching of heavy } \\
\text { metals }\end{array}$ & [2] \\
\hline 5 & $\begin{array}{c}\text { Primary and } \\
\text { secondary sludge }\end{array}$ & $\begin{array}{l}\text { Dry solid content, volatile } \\
\text { solids, TOC, } \mathrm{Pb}, \mathrm{Cd}, \mathrm{Cr}, \mathrm{Cu} \text {, } \\
\mathrm{Ni}, \mathrm{Hg}, \mathrm{Zn}\end{array}$ & $\begin{array}{l}\text { Waste management through } \\
\text { composting }\end{array}$ & Positive results & [9] \\
\hline 6 & $\begin{array}{l}\text { Paper sludge and } \\
\text { manure }\end{array}$ & $\begin{array}{l}\text { Macronutrients and } \\
\text { micronutrients and ammonia }\end{array}$ & $\begin{array}{l}\text { soil and biomass } \\
\text { production of willow }\end{array}$ & $\begin{array}{l}\text { Support the use of this } \\
\text { as fertilizer in soil } \\
\text { amendment }\end{array}$ & [7] \\
\hline 7 & $\begin{array}{l}\text { Secondary paper } \\
\text { sludge }\end{array}$ & Macro and micro nutrients & $\begin{array}{l}\text { Use as soil amendment/ fer- } \\
\text { tilizer in two Mediterranean } \\
\text { agricultural soils }\end{array}$ & $\begin{array}{l}\text { The plants growth } \\
\text { improved however } \\
\text { fertilizer with Mg were } \\
\text { added }\end{array}$ & [8] \\
\hline 8 & $\begin{array}{l}\text { De-watered pri- } \\
\text { mary and secondary } \\
\text { sludge }\end{array}$ & $\begin{array}{c}\text { Ammonia nitrogen, } \mathrm{P}, \mathrm{Cr}, \mathrm{Cu}, \\
\mathrm{Zn}, \mathrm{Ni}, \mathrm{Pb}, \mathrm{Cd}\end{array}$ & $\begin{array}{l}\text { Land application of pulp } \\
\text { mill sludge by GIS tools }\end{array}$ & Positive results & {$[10]$} \\
\hline 9 & $\begin{array}{l}\text { China paper and } \\
\text { pulp industry }\end{array}$ & Carbon emissions & $\begin{array}{l}\text { Estimation of carbon } \\
\text { footprints }\end{array}$ & Promt Cleaner production & {$[11]$} \\
\hline 10 & $\begin{array}{l}\text { Secondary pulp/ } \\
\text { paper-mill sludge } \\
\text { and waste } \\
\text { newspaper }\end{array}$ & $\begin{array}{c}\mathrm{Al}, \mathrm{Ba}, \mathrm{Ca}, \mathrm{Fe}, \mathrm{K}, \mathrm{Mg}, \mathrm{Mn} \\
\text { Na, P, S, Si, Zn }\end{array}$ & $\begin{array}{l}\text { investigate the effects of } \\
\text { reaction temperature and the } \\
\text { addition of selected } \\
\text { catalysts }\left(\mathrm{KOH}, \mathrm{HCO}_{2} \mathrm{H},\right. \\
\text { and } \mathrm{FeS}) \text { on product yields }\end{array}$ & $\begin{array}{l}\text { Positive results/ } \\
\text { Bio-crude production }\end{array}$ & {$[12]$} \\
\hline
\end{tabular}

$77 \%$ by 2020 . With the current levels of global paper consumption of around 400 million tons annually, as reported by the World Wildlife Fund (WWF), a staggering amount of residual bio-solids, $5-16 \%$ of paper production, were also produced depending on the type of product [3]. According to the Confederation of European Paper Industries (CEPI) [4], we have produced 91 million tons of paper and board, and so far the CEPI has suggested that recycling of paper waste and EU countries are recycling up to $71 \%$. Paper mill sludge is generated after the handling of the waste matter. Major parameters that influence the production of sludge include process and wastewater treatment technology. Per ton of paper manufacture usually generates $40-50 \mathrm{~kg}$ dry sludge and it is a combination of primary $(70 \%)$ and secondary (30\%) sludge [4-5]. In the near prospect, with the rise in paper manufacture, the relative amount of sludge will also be produced, demonstrating sludge management as a chief concern. On the other hand, there is also need to develop management strategies for pulp and paper mills.

Paper mill sludge is rich in organic contents, but also contains inorganics like clay, ash, fillers, etc. Numerous studies on the chemical composition of paper and pulp sludge implicate that it could be a rich source of organic matter (OM) and plant nutrients [6-7]. Paper mill biosolids contain several plant nutrients including $\mathrm{N}, \mathrm{P}$, potassium $(\mathrm{K}), \mathrm{Ca}$, and $\mathrm{Mg}$, along with other inorganic ions. Nutrient concentrations of paper mill bio-solids vary according to the pulping method and the level of microbial decomposition that has occurred during secondary treatment [8].

Land application is frequently practiced for sludge management. Composting is one stabilization technique used to prevent uncontrolled primary mill sludge (PMS) decay. Sludge improves soil properties and plant growth by increasing soil exposure to air, water-holding capacity, and water infiltration as well as lowering bulk density and surface crusting. Applications of industrial wastes like fertilizer and soil amendment have become popular in agriculture [9]. Pulp and paper mill by-products have been used for amending agricultural soils and producing crops, including corn [10]. Sludge is rich in macro and 
micro-contaminants, making it suitable for agricultural use [7]. However, heavy metals, organic compounds, and human pathogens and other contaminants are also present, which should be considered when it is utilized in agricultural soils [2]. Different management practices have been used for sludge management like composting, use as landfill cover material, land spreading, PMS use in energy, and use for production of building materials, etc. [3]. The chemical composition and its application from different sludge sources are given in (Table 1). However, the conversion of pulp and paper mill waste into biosolids is a promising technique since it is easy to perform and bio-solids have various applications in different fields. The pulp and paper mill sludge was conducted to appraise the bio-solid as a fertilizer in plants.

This study aimed at quantitatively assessing the macronutrients in bio-solids from paper and pulp waste. The principle objectives were to compare the primary and secondary sludge effects on biomass production, foliar nutrient concentration, and soil chemical properties with the effects of commercial fertilizer (urea) and untreated plants. In the present study we compared growth, nutrient level, and biomass of plants (A. esculentus and $M$. sachalinensis) containing primary and secondary biosolids with control plants.

\section{Materials and Methods}

\section{Sample Collection}

The Primary and secondary paper and pulp sludge (PPS) samples were collected from Packages Ltd Kasur plant. The PPS samples of about $2 \mathrm{~kg}$ were collected from two different waste sludge sites. They were stored at 4 . The primary mill sludge (PMS) was generated following initial husk treatment to generate good quality paper and flying paper. The $\mathrm{pH}$ of primary sludge was 6.5 and it was passed through aluminum hydroxide $\left[\mathrm{Al}(\mathrm{OH})_{3}\right]$ and caustic soda $(\mathrm{NaOH})$. The Secondary mill sludge (SMS) was obtained from pink rough tissue paper waste passed from primary treatment. The $\mathrm{pH}$ of secondary sludge is 7.5 due to a lot of microbial activity. Sludge was converted to bio-solid by dewatering it and air-drying it in a muffle furnace at 600 (Nabertherm). It was mixed and squeezed by hand so that large particles and lumps would be converted into smaller homogenized balls of bio-solids [11].

\section{Soil Analysis}

Soil surface sample $(2-5 \mathrm{~cm})$ were collected in bulk, air dried at room temperature, crushed, and sieved before use. The organic carbon content of the soil was determined by dichromate oxidation method [12]. Total $\mathrm{N}$ was determined by Kjeldahl method following the procedure [13]. Available $\mathrm{P}$ and $\mathrm{Ca}$ were determined by flame photometer [14].

\section{Sludge Analysis}

Moisture content was calculated from weight loss after oven-drying to a constant weight at 105; OM content was determined by loss on ignition at 450 for 4 hours [15]. For organic amendment, dry matter content $(90 \%)$ was determined by weight loss from oven drying at 60 . Ca and P were determined by flame photometer (JENWAY PEP7) and heavy metal contents by atomic absorption spectrometer (AAS) at PCSIR, Lahore, following the standard procedure as described by [14]. Nitrogen was estimated through Kjeldahl method following the procedure described by [13] in PCSIR, Lahore. Magnesium was determined by back titration. Other elements in sludge samples and soil were determined by ashing at 200 for 5 hours, the prepared ash was then digested in $6 \mathrm{~N}$ hydrochloric acid $(\mathrm{HCl})$ and internal standard were prepared by the ash samples for analysis by direct-reading flame photometer. The total dry matter (90 and $89.45 \%)$, total $\mathrm{C}(0.5,0.01 \%)$, total $\mathrm{N}$ $(7.5,1.7 \%)$ and $\mathrm{P}(0.8549,0.5946 \mathrm{mg} / \mathrm{Kg})$ were observed for PMS and SMS, respectively.

\section{Agronomic Practice}

Soil was mixed with primary bio-solid (PB) and secondary bio-solid (SB) separately at the rate of $2 \mathrm{~g}$ per pot and placed in $20 \mathrm{~cm}$ diameter pots. The first pot was a control plant grown under normal conditions without any fertilizer. In the Second and third pot PB and SB were used as fertilizer to monitor growth rate, plant biomass, and plant nourishment. The fourth pot was artificially grown plant with the help of synthetic fertilizer, i.e., urea. The pots were filled with $4 \mathrm{~kg}$ of subtract of the texture of sandy loamy soil. On January 15, about 15 seeds of ladyfinger (A. esculentus) were sown in each pot and kept in a warm place where sunlight was provided, with day temperature of about 22. Distilled water was daily added to the pots to increase the moisture content up to $70 \%$ of the soil water-holding capacity. Seedlings were thinned to $7 /$ pot two weeks after emergence. After 88 days, on 13 April all the plants were harvested. The impact of PB and SB were also experimented on the garden mint (M. sachalinensis) so that results could be compared to short- and long-life plants. On December 15, about 10 seeds of $M$. sachalinensis were sown in each pot and kept in a shaded area where direct sunlight could not reach but still enough sunlight was provided. The pots were kept at 19, and the soil was constantly kept moist and well drained. Each pot was watered regularly to keep the soil evenly moist. After 20 days, on 5 January all mint plants were harvested. Before the application of bio-solids, the soil in each pot was air dried, grounded, sieved $(2 \mathrm{~mm})$, and analyzed as described above. The subtract was also analyzed for any metallic pollution.

Soon after the application of PB and SB the soil of each pot of $A$. esculantus and $M$. Sachalinensis was again analyzed to measure the total macronutrients 
concentration taken up by the plants. The concentration of macronutrients in soil was again analyzed after 6 weeks of planting and it was observed that almost all the trace metals were utilized by the plants during their growth. After 6 weeks of growth in PB and SB the plants were harvested and biomass was weighed. The biomass obtained from primary and secondary plants were then compared to that of control and synthetic fertilizer amended in soil. The biomass of plants which were provided with $\mathrm{PB}$ was weighed more than the SB because the presence of macronutrients was observed to be more abundant in the PB. Therefore the growth rate and plants biomass after harvesting was much more in the pots with $\mathrm{PB}$, however the pots containing synthetic fertilizer (urea) were more lush because of excessive $\mathrm{N}$ availability.

\section{Results and Discussion}

\section{Sludge Composition}

The chemical characteristics of the primary and secondary sludge indicated that the concentrations of macronutrients $(\mathrm{N}, \mathrm{P}, \mathrm{Ca}, \mathrm{Mg})$ were higher in primary than secondary sludge; however, $\mathrm{Mg}$ was not detected in secondary sludge. The absorbance of $\mathrm{P}$ obtained by running the standards prepared $(5 \mathrm{ppm}, 10 \mathrm{ppm}, 20 \mathrm{ppm}$, $50 \mathrm{ppm}$, and $100 \mathrm{ppm}$ ) were $0.12,0.24,0.31,0.54$, and 0.92 , respectively. The concentration of $\mathrm{P}$ detected in the primary sludge was $0.86 \mathrm{mg} / \mathrm{kg}$ and in secondary sludge was $0.59 \mathrm{mg} / \mathrm{kg}$ which was slightly less than primary sludge (Table 1). In primary sludge the quantity of $\mathrm{Mg}$ was $0.01 \mathrm{mg} / \mathrm{kg}$, which is very low. The amount of $\mathrm{N}$ observed in primary and secondary sludge was $7.5 \%$ and $1.7 \%$, respectively. Ca was converted to percentage in primary and secondary sludge. $\mathrm{Ca}$ observed in primary sludge was $0.5 \%$, and $0.01 \%$ of $\mathrm{Ca}$ was calculated in secondary sludge [16].

In this study, sludge might be a good source of macronutrients for the growth of plants. In the paper finishing process, $\mathrm{CaCO}_{3}$ was used, which was the major source of $\mathrm{Ca}$ in sludge. Before treatment of sludge, urea is added for enhanced microbial activity, and this urea is the basic source of $\mathrm{P}$ and $\mathrm{N}$ in sludge. Ribeiro [10] reported that the paper mill sludge produced in Cova da Beira region (Portugal) contained $\mathrm{OM}, \mathrm{N}$, and $\mathrm{P}$ at the rate of $11-47 \%$, $38-2,560 \mathrm{mg} / \mathrm{kg}$, and $167-370 \mathrm{mg} / \mathrm{kg}$, respectively, which showed a significant increase in soil productivity. The permissible limit for heavy metals in the sludge appropriate for land application is given in Table 2 [16-25]. Heavy metals in the soil were below the limits of $\mathrm{N}$ and $\mathrm{P}$ concentrations in soil and did not present any risk of nutrients leaching in the soil. GIS tool was used to manage sludge in the field application.

Primary sludge $\mathrm{pH}$ was in the acidic (6.5) range because the primary sludge is obtained after it passes through some chemical treatment that involves alumina
Table 2. Permissible and experimental values of heavy metals in sludge.

\begin{tabular}{|c|c|c|}
\hline \multirow{2}{*}{ Heavy metals } & Permissible limits & $\begin{array}{c}\text { Heavy metals } \\
\text { content in sludge }\end{array}$ \\
\cline { 2 - 3 } & \multicolumn{2}{|c|}{$\mathrm{mg} / \mathrm{Kg}$ dry weight } \\
\hline Cadmium & 85 & 64 \\
\hline Chromium & 3000 & 2110 \\
\hline Lead & 840 & 450 \\
\hline Nickel & 420 & 230 \\
\hline Zinc & 7500 & 6500 \\
\hline Mercury & 57 & 15 \\
\hline
\end{tabular}

$\left(\mathrm{Al}_{2} \mathrm{O}_{3}\right)$ and $\mathrm{NaOH}$. The appearance of primary sludge was dark brown. The secondary sludge $\mathrm{pH}$ measured was in basic (7.5) range and its appearance was light brown. The temperature of primary sludge was 32 and the temperature of secondary sludge was $28^{\circ} \mathrm{C}$.

In utilization of bio-solids the most important environmental factor is $\mathrm{pH}$. Optimum $\mathrm{pH}$ in the range of (7-8) is required for the sustainability of microorganism in the bio-solids. Hazarika [2] reported that the maximum increase in $\mathrm{pH}$ was observed ranging from 7.6-8.1 during composting. Because of an increase in microbial activity a gradual rise in temperature was also observed [22-25].

\section{Soil Analysis}

Before the application of sludge on sandy loam soil, the concentrations of macronutrient $\mathrm{N}, \mathrm{P}, \mathrm{Ca}$, and $\mathrm{Mg}$ were tested and $\mathrm{pH}$ was also measured. Sandy loam soil contained $0.86 \mathrm{mg} / \mathrm{kg}$ concentration of P. It was detected that $\mathrm{N}$ at concentration of $7.5 \%$ and $\mathrm{Ca}$ at $0.5 \%$ were already present in soil, and $\mathrm{Mg}$ was not detected in soil sample (Table 3). The $\mathrm{pH}$ of sandy loam soil was in the acidic (4.5) range.

\section{Effect on Soil Properties}

\section{Soil of Abelmoschus Esculentus}

After the application of sludge into the soil the concentrations of macronutrients were measured in the A. esculantus plants. The concentrations of $\mathrm{P}$ and $\mathrm{N}$ in control pot were $(0.003 \mathrm{mg} / \mathrm{Kg}, 0.01 \%)$, but $\mathrm{Ca}$ and $\mathrm{Mg}$ were not detected. The plants in which PB was applied showed the highest concentrations of $\mathrm{P}, \mathrm{N}, \mathrm{Ca}$, and $\mathrm{Mg}$ $(0.087 \mathrm{mg} / \mathrm{Kg}, 3.1 \%, 1.3 \%, 0.008 \mathrm{mg} / \mathrm{kg}$ ) (Table 3). The secondary pot did not contain any $\mathrm{Ca}$ and $\mathrm{Mg}$, while concentrations of $\mathrm{P}$ and $\mathrm{N}$ were $(0.067 \mathrm{mg} / \mathrm{Kg}, 1.3 \%)$. Soil was assessed again to evaluate metals after about 6 weeks of sludge application. $\mathrm{N}$ and $\mathrm{P}$ concentrations in primary sludge were $0.6 \%$ and $0.01 \%$, while in secondary sludge pots the concentration was $0 \%$. Ca and 
Table 3. Chemical characteristics of unamended soil and macronutrients in A. esculentus and M. saccalinensis plants soon after application.

\begin{tabular}{|c|c|c|c|c|c|c|}
\hline Chemical properties & $\mathrm{pH}$ & $\mathrm{Ca}(\%)$ & Total N (\%) & $\mathrm{C}: \mathrm{N}(\%)$ & $\mathrm{P}(\mathrm{mg} / \mathrm{kg})$ & $\mathrm{Mg}(\mathrm{mg} / \mathrm{kg})$ \\
\hline Concentrations & 4.5 & 0.5 & 8.5 & $10: 1$ & 0.86 & --- \\
\hline \multicolumn{7}{|c|}{ Concentrations of macronutrients } \\
\hline \multicolumn{7}{|c|}{ A. esculentus } \\
\hline Sludge & $\mathrm{P}(\mathrm{mg} / \mathrm{kg})$ & $\mathrm{N}(\%)$ & $\mathrm{Ca}(\%)$ & $\mathrm{Mg}(\mathrm{mg} / \mathrm{kg})$ \\
\hline Primary & 0.087 & 3.1 & 1.3 & 0.008 \\
\hline Secondary & 0.067 & 1.3 & 0.85 & -- \\
\hline Control & 0.003 & 0.01 & 0.17 & --- \\
\hline \multicolumn{7}{|c|}{ M. Sachalinensis } \\
\hline Primary & 0.093 & 3 & 1.0 & 0.001 \\
\hline Secondary & 0.058 & 0.9 & 0.041 & --- \\
\hline Control & 0.002 & 0.02 & 0.01 & -- \\
\hline
\end{tabular}

$\mathrm{Mg}$ assessed in control, primary, and secondary were $0 \%$ (Fig. 1). After observing for weeks it was found that all the macronutrients were absorbed by the plants during their growth [26-29].

The $\mathrm{pH}$ of plants soil in this study indicated that the $\mathrm{pH}$ of soil increased gradually because of the addition of sludge and availability of the base cation. The concentrations of $(\mathrm{P}, \mathrm{Mg}, \mathrm{N}$, and $\mathrm{Ca})$ in primary sludge-amended plants were $(97 \%, 0.008 \%$, $99.67 \%$, and $86.92 \%$ ) higher verses control plant (Plants amended with secondary sludge had (95\%, $0 \%, 99 \%$, and $80 \%$ ) more macronutrients then control plant (.The results of the present study were in line with previous studies, which demonstrate that sludge application increases the OM content of the soil. N'Dayegamiye [6] reported in this study that different organic amendments were used as treatment to increase soil productivity. The paper mill sludge used in this study consisted of paper mill sludge with $\mathrm{C} / \mathrm{N}$ ratio $<15$ (PMS1) and paper mill sludge with $\mathrm{C} / \mathrm{N}>15$ (PMS2) applied alone or supplemented with mineral fertilizer at a rate of $90 \mathrm{~kg} \mathrm{~N} \mathrm{ha-1}$. The rate of fertilizer application was based on the rate of nutrient concentrations required by the plant. Nitrogen was also detected in the fertilizers. The $\mathrm{N}$ fertilizer rate in the unamended control consisted of 0 and $150 \mathrm{~kg} \mathrm{~N} \mathrm{ha}{ }^{-1}$. PMS alone
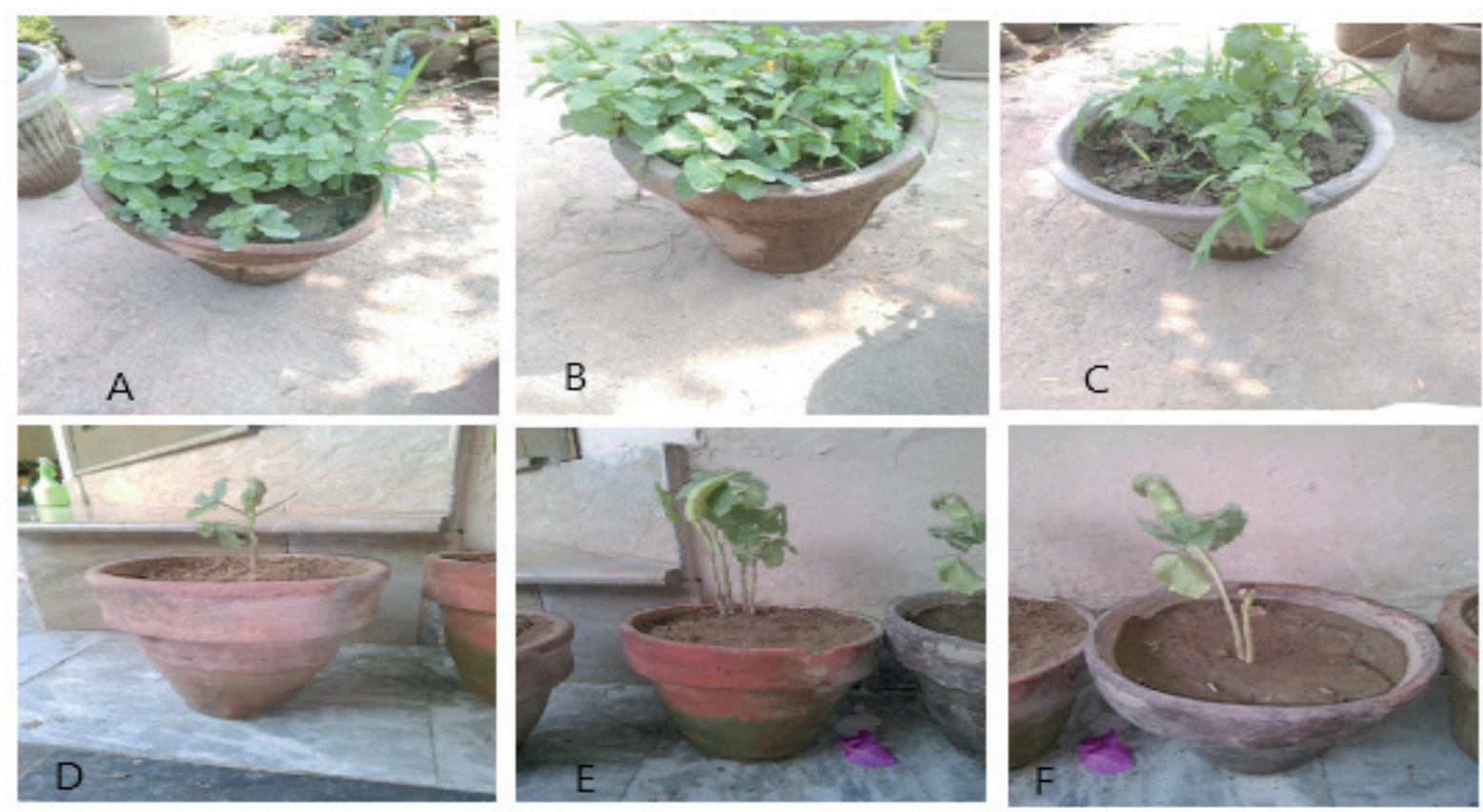

Fig. 1. Pot experiments for mint, A, B (sludge), and C (control); for lady finger, D, E (sludge), and F (control). 
significantly increased $\mathrm{N}$ uptake and potato marketable yields by 2.5 to $16.4 \mathrm{Mg} \mathrm{ha}^{-1}$ compared to the unfertilized control.

\section{Soil of Mentha Sacalinenesis}

In the control plants the concentrations of $\mathrm{P}, \mathrm{N}$, and Ca were $0.002 \mathrm{mg} / \mathrm{kg}, 0.02 \%$ and $0.01 \%$, respectively. The concentrations of $(\mathrm{P}, \mathrm{N}, \mathrm{Ca}$, and $\mathrm{Mg})$ detected in M. sachalinensis pots amended with primary sludge were $0.093 \mathrm{mg} / \mathrm{Kg}, 3.0 \%, 1.0 \%$, and $0.001 \mathrm{mg} / \mathrm{Kg}$, respectively. Soil of $M$. sachalinensis pots that were amended with secondary bio-solids showed lower concentrations of $\mathrm{P}, \mathrm{N}$, and $\mathrm{Ca}(0.058 \mathrm{mg} / \mathrm{Kg}, 0.91 \%$, $0.041 \%$ ), whereas $\mathrm{Mg}$ was not detected. After 6 weeks the soil was again analyzed to measure the $\mathrm{N}, \mathrm{P}, \mathrm{Ca}$, and $\mathrm{Mg}$ concentrations. Only $\mathrm{N}$ in primary bio-solids pots was assessed at $0.1 \%$. Ca, $\mathrm{Mg}$, and $\mathrm{P}$ were not detected in them. Calcium was assessed at $0 \%$ in both primary and secondary bio-solids pots.

Nunes [15] studied the impact of secondary paper sludge under greenhouse conditions on wheat (Triticumaestivum L.). Authors used two agricultural Mediterranean soils: Cambic Arenosol (cmAR) and a Cromic Cambisol (crCM). Four sludge rates were utilized in this study ranging from 0 to $40 \mathrm{~g} / \mathrm{kg}$ (equivalent of $0,38,88$, and $120 \mathrm{Mg} / \mathrm{ha}$ ). A significance increase in $\mathrm{pH}$, $\mathrm{P}$, total $\mathrm{N}$, and $\mathrm{K}$ availability was observed in the soil. A significant increase in $\mathrm{N}$ and decreases in $\mathrm{Zn}, \mathrm{Mn}$, and $\mathrm{Cu}$ concentrations were observed in wheat. Due to the unavailability of $\mathrm{Mg}$, wheat grain yields were reduced by $33 \%$ and $37 \%$ when $120 \mathrm{Mg}$ secondary paper sludge per ha was applied to cmAR and crCM soils. However, straw yields with much lower
$\mathrm{Mg}$ requirements increased significantly with secondary paper sludge rates.

\section{Effect on Plant Growth}

\section{Plant Biomass of A. Esculentus}

After 6 weeks of growth in primary and secondary bio-solids the plants were harvested and biomass was calculated to estimate plant growth. The biomass obtained from primary and secondary plants were then compared to that of control and synthetic fertilizer amended in soil. The weight of biomass of control was $0.15 \mathrm{~kg}$; the plant biomass of primary bio-solid was $0.5 \mathrm{~kg}$, and plants with secondary bio-solid calculated showed $0.2 \mathrm{~kg}$ and urea containing plants weighed $1.22 \mathrm{~kg}$. The plants of M. sachalinensis were also harvested after 6-week growth in primary and secondary sludge. The obtained biomasses of primary and secondary were then compared with control and synthetic fertilizer (urea). The weighed biomass of control was $0.1 \mathrm{~kg}$, the primary bio-solid used in $M$. sachalinensis plant biomass weighed $0.45 \mathrm{~kg}$, and secondary bio-solid used in M. Sachalinensis plant biomass weight was $0.2 \mathrm{~kg}$ (Table 4). The weighed biomass of these plants were compared with the biomass of the synthetic fertilizer (urea) that was $1.05 \mathrm{~kg}$.

Quaye [8] studied the effect on shrub willow (Salix dasyclados SV1) by paper sludge and dairy manure used as bio-fertilizer. Foliar nutrient concentration and soil chemical properties were analyzed in this study to observe the total plant growth in the season. Fertilization did not increase the biomass production of the yield. However, N-poor paper sludge also did not decrease yield

Table 4. Percentage of nutrients in primary and secondary sludge (without fertilizer) and estimation of total plant biomass weight.

\begin{tabular}{|c|c|c|c|c|}
\hline \multicolumn{5}{|c|}{ A. Esculentus } \\
\hline Sludge type & $\mathrm{P}(\%)$ & $\mathrm{N}(\%)$ & $\mathrm{Ca}(\%)$ & $\operatorname{Mg}(\%)$ \\
\hline Primary & 96.55 & 99.67 & 86.92 & 0.008 \\
\hline Secondary & 95.52 & 99.23 & 80 & --- \\
\hline Difference & 1.066 & 0.441 & 7.96 & 0.008 \\
\hline \multicolumn{5}{|c|}{ M. Sacalinenesis } \\
\hline Primary & 97.84 & 99.33 & 99 & 0.001 \\
\hline Secondary & 96.55 & 97.77 & 75.60 & --- \\
\hline Difference & 1.33 & 1.570 & 23.63 & 0.001 \\
\hline \multicolumn{5}{|c|}{ Estimation of total plant biomass weight } \\
\hline Sludge & Concentration (g/pot) & A. Esculentus (kg) & \multicolumn{2}{|c|}{ M. Sachalinensis $(\mathrm{kg})$} \\
\hline Control & --- & 0.15 & \multicolumn{2}{|c|}{0.1} \\
\hline Primary & 2 & 0.5 & \multicolumn{2}{|c|}{0.45} \\
\hline Secondary & 2 & 0.2 & \multicolumn{2}{|c|}{0.2} \\
\hline Urea & 0.5 & 1.22 & \multicolumn{2}{|c|}{1.05} \\
\hline
\end{tabular}


because of the nutrient status of the site or nutrient loss in the site.

\section{Effect on Plant Nutrients}

The percentage of macronutrients was higher in primary bio-solid pots as compared to secondary bio-solids pots. The negative control plants (without fertilizers) had low concentrations as compared to primary sludge and secondary sludge. However, positive control plant (with synthetic fertilizer, i.e., urea) had the highest nutrients concentration. The order of nutrients concentration in $A$. esculantus plants were pCPSC. The concentration of $\mathrm{P}$ was $1.066 \%$ higher in pots with primary bio-solids versus secondary bio-solid. The plants provided primary bio-solids and showed $0.44 \%$ more $\mathrm{N}$ as compared to secondary bio-solid plants. Ca concentration in primary bio-solid plants was $7.96 \%$ more than the secondary plant [26-37].

Hazarika [2] reported in his studies that a steady increase was observed in total concentration of macronutrients $(\mathrm{Na}, \mathrm{K}$ and $\mathrm{Ca}$ ) until the end of the composting process. The order of total concentration was $\mathrm{Ca}>\mathrm{Na}>\mathrm{K}$. For $\mathrm{Na}, \mathrm{K}$, and $\mathrm{Ca}$ the total increases during the composting process were $1.2 \%, 51.8 \%$, and $49.5 \%$, respectively.

\section{Conclusions}

Based on present results, this study demonstrates that the use of paper and pulp bio-solids in manufactured topsoil significantly increase soil fertility and create a favorable growing medium for plants by improving soil qualities and gradually increasing nutrients necessary for growth. In particular, primary sludge showed a significant effect on soil fertility, plant biomass, and nutrient concentration. The concentration of macronutrients was observed to be highest in primary sludge than secondary and control plan (negative). However, primary and secondary sludge had more favorable effect on yields produced by $A$. esculentus and M. Sachalinensis plants than the control plant.

\section{Conflict of Interest}

The authors declare no conflict of interest.

\section{References}

1. RENBI A., CARLSON J., DELSING J. Impact of PCB manufacturing process variations on trace impedance. International Symposium on Microelectronics 2011 (1), 891, 2011.

2. HAZARIKA J., GHOSH U., KALAMDHAD A.S., KHWAIRAKPAM M., SINGH J. Transformation of elemental toxic metals into immobile fractions in paper mill sludge through rotary drum composting. Ecol. Eng. 101, 185, 2017.

3. XU C., LANCASTER J. Conversion of secondary pulp/ paper sludge powder to liquid oil products for energy recovery by direct liquefaction in hot-compressed water. Water Res. 42 (6-7), 1571, 2008.

4. WIERZBOWSKA J., SIENKIEWICZ S., KRZEBIETKE S., STERNIK, P. Sewage sludge as source of nitrogen and phosphorus for Virginia fanpetals. Bulgarian J. Agri. Sci. 22 (5), 722, 2016.

5. GAGNON B., ZIADI N., CO^TE C., FOISY M. Environmental impact of repeated applications of combined paper mill bio-solids in silage corn production. Can. J. Soil Sci. 90 (1), 215, 2010.

6. N'DAYEGAMIYE A., NYIRANEZA J., GIROUX M., GRENIER M., DRAPEAU, A. Manure and paper mill sludge application effects on potato yield, nitrogen efficiency and disease incidence. Agronomy, 3 (1), 43, 2013.

7. QUAYE A.K., VOLK T.A., HAFNER S., LEOPOLD D.J., SCHIRMER C. Impacts of paper sludge and manure on soil and biomass production of willow. Biomass Bioenerg. 35 (7), 2796, 2011.

8. NUNES J.R., CABRAL F., LOPEZ-PINEIRO A. Shortterm effects on soil properties and wheat production from secondary paper sludge application on two Mediterranean agricultural soils. Bioresour. Technol. 99 (11), 4935, 2008.

9. MONTE M.C., FUENTE E., BLANCO A., NEGRO C. Waste management from pulp and paper production in the European Union. Waste Manage. 29 (1), $293,2009$.

10. RIBEIRO P., ALBUQUERQUE A., QUINTA-NOVA L., CAVALEIRO V. Recycling pulp mill sludge to improve soil fertility using GIS tools. Resour. Conserv. Recy. 54 (12), 1303, 2010.

11. WANG Y., YANG X., SUN M., MA L., LI X., SHI L. Estimating carbon emissions from the pulp and paper industry: A case study. Appl. Energ. 184, 779, 2016.

12. ZHANG L., CHAMPAGNE P., XU C.C. Bio-crude production from secondary pulp/paper-mill sludge and waste newspaper via co-liquefaction in hot-compressed water. Energy, 36 (4), 2142, 2011.

13. ZWIETEN L.V., KIMBER S., MORRIS S., CHAN K.Y., DOWNIE A., RUST J., JOSEPH S., COWIE A. Effects of biochar from slow pyrolysis of paper mill waste on agronomic performance and soil fertility. Plant. Soil. 327 (1-2), 235, 2010.

14. CEPI. Key statistics 2012 - European pulp and paper industry. Brussels: Confederation of European Paper Industries, 2013.

15. MOUNTOURIS A., VOUTSAS E. TASSIOS D. Plasma gasification of sewage sludge: process development and energy consumption. Energ. Convers. Manage. 49 (8), 2264, 2008.

16. CAMBERATO J.J., GAGNON B., ANGERS D.A., CHANTIGNY M.H., PAN W.L. Pulp and paper mill by-products as soil amendments and plant nutrient sources. Can. J. Soil Sci. 86 (4), 641, 2006.

17. LIU Z., LI J., LI P., LI Y., LI W. Study of Bioretention System on Heavy-Metal Removal Effect. Pol. J. Environ. Stud. 27 (1), 163, 2018.

18. TAHIR M., IQBAL M., ABBAS M., TAHIR M.A., NAZIR A., IQBAL D.N., KANWAL Q., HASSAN F., YOUNAS U. Comparative study of heavy metals distribution in soil, forage, blood and milk. Acta Ecol. Sinica. 37 (3), 207, 2017.

19. YOUNAS U., IQBAL S., SALEEM A., IQBAL M., NAZIR A., NOUREEN S., MEHMOOD K., NISAR N. Fertilizer 
industrial effluents: Physico-chemical characterization and water quality parameters evaluation. Acta Ecol. Sinica. 37 (4), 236, 2017.

20. QAMAR A., ASI R., IQBAL M., NAZIR A. Survey of Residual Pesticides in Various Fresh Fruit Crops: A Case Study. Pol. J. Environ. Stud. 26 (6), 2703, 2017.

21. BABARINDE A., OGUNDIPE K., SANGOSANYA K.T., AKINTOLA B.D., HASSAN A.-O.E. Comparative study on the biosorption of $\mathrm{Pb}(\mathrm{II}), \mathrm{Cd}(\mathrm{II})$ and $\mathrm{Zn}(\mathrm{II})$ using Lemon grass (Cymbopogon citratus): kinetics, isotherms and thermodynamics, Chem. Int. 2, 89, 2016.

22. BABARINDE A., ONYIAOCHA G.O. Equilibrium sorption of divalent metal ions onto groundnut (Arachis hypogaea) shell: kinetics, isotherm and thermodynamics, Chem. Int. 2, 37, 2016.

23. BENABDALLAH N.K., HARRACHE D., MIR A., DE LA GUARDIA M., BENHACHEM F.-Z. Bioaccumulation of trace metals by red alga Corallina elongata in the coast of Beni Saf, west coast, Algeria. Chem. Int. 1 3, 220, 2017.

24. SASMAZ M., AKGUL B., YILDIRIM D., SASMAZ A. Bioaccumulation of thallium by the wild plants grown in soils of mining area. Int. J. Phytoremediat. 18, 1164, 2016.

25. SASMAZ M., AKGUL B., YILDIRIM D., SASMAZ A. Mercury uptake and phytotoxicity in terrestrial plants grown naturally in the Gumuskoy (Kutahya) mining area, Turkey. Int. J. Phytoremediat. 18, 69, 2016.

26. MEERSMANS J., VAN WESEMAEL B., VAN MOLLE M. Determining soil organic carbon for agricultural soils: a comparison between the Walkley \& Black and the dry combustion methods (north Belgium). Soil Use Manage. 25 (4), 346, 2009.

27. WANG H., PAMPATI N., MCCORMICK W.M., BHATTACHARYYA L. Protein nitrogen determination by Kjeldahl digestion and ion chromatography. J. Pharm. Sci. 105 (6), 1851, 2016.
28. KAUR K., SOHPAL K.V. Characterization and optimization of calcium and phosphate based material for mitigation of fluoride in ground water. J. Appl. Res. Water Wastewater, 3 (1), 217, 2016.

29. BHATTI H.N., JABEEN A., IQBAL M., NOREEN S., NASEEM Z. Adsorptive behavior of rice bran-based composites for malachite green dye: Isotherm, kinetic and thermodynamic studies. J. Mol. Liq. 237, 322, 2017.

30. BHATTI H.N., ZAMAN Q., KAUSAR A., NOREEN S., IQBAL M. Efficient remediation of $\mathrm{Zr}(\mathrm{IV})$ using citrus peel waste biomass: Kinetic, equilibrium and thermodynamic studies, Ecol. Eng. 95, 216, 2016.

31. UKPAKA C. Empirical model approach for the evaluation of $\mathrm{pH}$ and conductivity on pollutant diffusion in soil environment. Chem. Int. 2, 267-278, 2016c.

32. UKPAKA C.P., UKPAKA C. Characteristics of groundwater in Port-Harcourt local Government area. Chem. Int. 2, 136, 2016.

33. IQBAL M. Vicia faba bioassay for environmental toxicity monitoring: a review, Chemosphere, 144, 785, 2016.

34. TAHIR N., BHATTI H.N., IQBAL M., NOREEN S. Biopolymers composites with peanut hull waste biomass and application for Crystal Violet adsorption, Int. J. Biol. Macromol. 94, 210, 2016.

35. CHAIJAK P., LERTWORAPREECHA M., SUKKASEM C. Phenol Removal from Palm Oil Mill Effluent Using Galactomyces reessii Termite-Associated Yeast. Pol. J. Environ. Stud. 27 (1), 39, 2018.

36. GUAN B.T.H., MOHAMAT-YUSUFF F., HALIMOON N., YONG C.S.Y. Mn- and Cd-Contaminated Wild Water Spinach: in vitro Human Gastrointestinal Digestion Studies, Bioavailability Evaluation, and Health Risk Assessment. Pol. J. Environ. Stud. 27 (1), 79, 2018.

37. LU D., HUANG Q., DENG C., ZHENG Y. Phytoremediation of Copper Pollution by Eight Aquatic Plants. Pol. J. Environ. Stud. 27 (1), 175, 2018. 